\title{
Development of Islamic Religious Education Learning Model based on Multicultural Values
}

\author{
Amiruddin Amiruddin ${ }^{1 *}$ Askar Askar ${ }^{2}$, and Yusra Yusra ${ }^{3}$ \\ ${ }^{1}$ Islamic Education Department, Postgraduate, Institut Agama Islam Negeri Palu \\ ${ }^{2}$ Islamic Education Department, Postgraduate, Institut Agama Islam Negeri Palu \\ ${ }^{3}$ Islamic Education Department, Postgraduate, Institut Agama Islam Negeri Palu
}

\section{ABSTRACT}

The focus of this study is to examine the design development of multicultural value-based Islamic education learning models at the high school level. This research is a qualitative research. Data collection is done by observation, interview and documentation. While the data analysis technique used is data reduction, data presentation, data verification and drawing conclusions. The results of the study showed that, the design of the development of the learning model that determined multicultural values, which were integrated in the Islamic Religious Education subject, b) syllabus, c) lesson plan, d) used the islamic education learning model based on multicultural values, and c) conducted an assessment towards the process of learning activities, which is a follow-up to learning, the approach to developing learning models, namely the approach to justice and equality without discrimination, called cultural pluralism, which provides opportunities and freedom for all elements to show and develop their respective identities, both from language, ethnicity, religion and so on. While developing models of Islamic education learning based on multicultural values because; a) multicultural education is not a special subject, b) promotes equality between students of different backgrounds, c) the diversity of students that causes misunderstandings that can lead to disputes between fellow students.
ARTICLE

INFORMATION

Keywords:

Design, learning, multicultural, Islamic education, schools 


\section{Introduction}

Pluralism can build social strength and good diversity to compile one another in synergy in building cooperation. However, pluralism can also lead to conflict and the compilation struggle is not properly and properly fostered. For example riots and conflicts with sara, ethnic, traditional, racial and religious backgrounds. If traced the root causes of the conflict are indeed quite diverse. There are economic factors, political politics, power struggles, or misunderstandings between religions and so on. ${ }^{1}$

The emergence of these problems can occur from various fields such as social, political, cultural, economic and educational. To solve problems that arise from various fields certainly requires strategy. The education sector is seen as the most potential to instill the values of togetherness, unity, and closeness between ethnic, racial, religious and cultural diversity. This is as stated in the law of the Republic of Indonesia No. 20 of 2003 concerning national education:

National education functions to develop and shape the dignified character and civilization of the nation in the context of developing the intellectual life of the nation, aiming at developing the potential of students to become people of faith and devotion to

\footnotetext{
${ }^{1}$ Ngainun Naim dan Ahmad Syauqi, Pendidikan Multikultural; Konsep dan Aplikasi, (Yogyakarta; Ar-Ruzz Media, 2008), 15
}

God Almighty, having noble, healthy, knowledgeable, capable, creative, independent and becoming a democratic citizen and responsible. ${ }^{2}$

Based on the explanation of the law that the function and purpose of national education is to form human beings who are noble, healthy, knowledgeable, capable, creative, independent and to be democratic and responsible citizens. This shows students have different attitudes that must respect each other. Because one of the functions of the Educational Institution is to do social integration, which is to unite children from a variety of diverse cultures and develop societies that have relatively heterogeneous shared values, the Educational Institution is expected to instill attitudes to students to respect people, race, ethnicity, culture, religion and other beliefs.

Islamic Education based on multicultural values is one of the solutions to get to know students in a variety of differences and diversity while at the same time it is hoped that they can familiarize students with an attitude of respecting these various conditions and diversity. According to James A.Banks, quoted by Azyumardi Azra defines multicultural education as "an emerging field of study and discipline whose main purpose is to create equal educational

\footnotetext{
${ }^{2}$ Undang-undang Sisdiknas (Sistim Pendidikan Nasional) 2003, (Jakarta; Cet. I, Sinar Grafika, 2003), 2
} 
opportunities for students of different races, ethnicities, social classes and cultural groups". ${ }^{3}$ So that through the implementation of Islamic Education that integrates multicultural values will help students understand, accept and respect other people with different ethnic, cultural and personality values in daily life.

Islamic Education Learning is based on multicultural values where the students are guided and directed so that they do not commit crimes against students with different educational backgrounds, ethnic groups, religions, languages and skin color. The goal is to be able to get to know each other and appreciate these differences, because Islamic Education based on multicultural values becomes important to appreciate the differences that exist while learning to respect these differences.

The role of teachers is an important factor in making strategies in developing learning models to implement the values of diversity in schools, teachers have an important role in multicultural education because teachers are one of the targets of this learning strategy. Therefore an Islamic Education teacher is expected to be able to understand and instill muticultural values that are integrated in Islamic Education so as

\footnotetext{
${ }^{3}$ Azyumardi Azra, Dari Pendidikan Kewarganegaraan hingga Pendidikan Multikultural; Pengalaman Indonesia, dalam Edukasi, Jurnal Penelitian Pendidikan Agama dan Keagamaan, (Vol,2, No. 4, Tahun 2004), 4
}

to give birth to students who are tolerant, compassion, empathy, justice, nationalism and other multicultural values. Thus, it needs to start from the multicultural-based learning process that is a learning process that is more directed at efforts to appreciate the differences between human beings so that the realization of calm in social life.

$$
\text { Islamic Education based on }
$$

multicultural values brings the agenda and principles of diversity, equality and respect for others, so that the universal message of education can be felt by all parties, through this aspect lies the urgency of teaching Islamic Education based on multicultural values in education, by educating students or school residents not to do things that are not appropriate to be done which can reduce the togetherness of life in diversity.

The development of the Islamic Religious Education learning model, referring to the standard process by internalizing multicultural values, so that it can be achieved, it needs to be further developed and elaborated on learning tools. Especially the Syllabus and Lesson Plan that has packed multicultural values. Educators who become learning "actors" do the mapping of Islamic Education Content Standards, so that it can be clearly known which Core Competencies and Basic Competencies can be internalized by multicultural education. 
The development of indicators aimed at multicultural values is a priority, because in that way materials can be obtained that are in accordance with the direction and objectives of multicultural education. Learning by integrating multicultural values in Islamic Education should not deny aqeedah from students. In order not to get caught up in these matters, it is better to avoid things that intersect with Aqeedah.

Based on the foregoing, educators are the spearhead of multicultural value-based education. The role of educators is crucial in the success of encouraging cross-cultural understanding of students. What educators say, the way a teacher teaches, and the educator's personality greatly influences the success of learning.

Therein lies the urgency of learning Islamic Education based on multicultural values where students are guided and directed so that they do not commit crimes against students with different educational backgrounds, ethnicity, language and skin color. The goal is to be able to get to know each other and appreciate these differences, because multicultural education becomes important to appreciate the differences as well as learn to respect these differences.

Senior High School 4 Palu is one of the school implementing multicultural valuebased learning in its educational institutions. This is based on the diversity that exists in these educational institutions, both in terms of teachers and aspects of students. The diversity that is owned by Senior High School 4 Palu is the diversity of backgrounds of students 'abilities, ethnicity, religion, parents' profession, residence, and various other diverse backgrounds.

\section{Literature Review}

\subsection{Previous Study}

Previous study is study that has been done by previous researchers and has been tested for its correctness based on the research method used. The research can be used as a reference as a comparison between current research and previous ones related to the current research title.

1. Saiful's Thesis on the Implementation of Multicultural Learning in Islamic Religious Education at Senior High School 6 Sigi. This study uses a class action technique that focuses on learning Islamic Education in Class XI IPS-2. The focus of the research is: First, the steps of classroom action research on Islamic Education in the class are the target of research. The second examines the results of the implementation of Islamic Education learning integrated with multicultural values in the first cycle and the third examines the results of the implementation of Islamic Education learning that are integrated 
with multicultural values in the second cycle, so that conclusions are obtained about the application of Islamic Education based on the values of multicultural values that can improve student learning outcomes ${ }^{4}$.

2. Arifinur's Thesis on the Implementation of Multicultural Islamic Education Learning (Case Study in Indonesia Good Morning Senior High School, Batu City). The research on the thesis is focused on: first, emphasizing learning planning emphasizes the integration of multicultural values: fair, responsible, religious, awareness of rights and obligations, equality, tolerance, respect for diversity, honesty, discipline contained in the Lesson Plan (RPP) and in syllabus. Second, the implementation of learning applies multicultural values in planning, but the most prominent are the values of togetherness and mutual respect without looking for differences. Third, implement an evaluation model that takes into account mutural values that are integrated in the Cognitive, Psycho-motor and affective shutter ${ }^{5}$.

${ }^{4}$ Saiful, Penerapan Pembelajaran Multikultural pada Pendidikan Agama Islam di SMA Negeri 6 Sigi, Tesis IAIN Palu 2014, (tidak diterbitkan), xi.

${ }^{5}$ Arifinur, Implementasi Pembelajaran Pendidikan Agama Islam Berwawasan Multikultural (Studi Kasus di SMA Selamat Pagi Indonesia Kota Batu), Tesis UIN Maulana Malik Ibrahim Malang 2013, (tidak diterbitkan), xii.
3. Ihsan's Thesis on Strategies of Islamic Education Teachers to Embed Multicultural Values in Junior High School 1 Bima City. The focus of this research are; first, how are multicultural values embedded in Junior High School 1 Bima through Islamic Education. Second, how is the Islamic Education teacher's strategy in instilling multicultural values through Islamic education in Junior High School 1 Bima ${ }^{6}$.

4. Journal written by Wardatul Baldah, Cecep Sumarna and Bambang Yuniarto, on the Effects of Multicultural Values on the Formation of Pluralist Attitudes of Students in Madrasah Tsanawiyah Babakan Ciwaringi Cirebon District, The Journal focused on: first, the planting of multicultural values is done by the teacher by inserting multicultural values in the learning method or strategy with a humanist approach. secondly, the formation of pluralist attitudes in Madrasah Tsanawiyah Babakan Ciwaringi can be said to be good, because the formation of pluralist attitudes of students is marked by the attitude of students who have begun to

${ }^{6}$ Ihsan, Strategi Guru Pendidikan Agama Islam dalam menanamkan nilai-nilai Mutikultural di SMP Negeri 1 Kota Bima, Tesis UIN Maulana Malik Ibrahim Malang 2014,(tidak diterbitkan), viii 
recognize and appreciate the differences. ${ }^{7}$.

Based on the description of the previous research, it can be understood that the author's thesis has a different substance with some of the research, because the writer in this thesis research is focused on the development of the Islamic Education Learning Model based on multiculturalism in Senior High School 4 Palu. So it does not violate the provisions in scientific research.

\subsection{Learning Models}

The learning model is basically a form of learning illustrated from beginning to end that is presented typically by the teacher. In other words the learning model is a wrapper or frame of the application of an approach, method, and learning technique. ${ }^{8}$

The learning model has a broader meaning than the learning strategy, method, or procedure. The term learning model has 4 special characteristics that do not have a learning strategy or method, namely:

1) Logical theoretical rationales compiled by educators.

2) Learning objectives to be achieved.

3) Teaching steps are needed so that the learning model can be implemented optimally.

\footnotetext{
${ }^{7}$ Wardatul Baldah, Cecep Sumarna dan Bambang Yuniarto, Pengaruh Penanaman Nilai-nilai Multikultural terhadap Pembentukan Sikap Pluralis Siswa di MTsN Babakan Ciwaringin Kabupaten Cirebon, Jurnal Edueksos Volume V; No. I Juni 2016, 122-123.

${ }^{8}$ Kokom Komulasari, Pembelajaran Kontekstual Konsep dan Apliasi, (Bandung; PT. Refika Aditama, 2010), 57
}

4) The learning environment needed for learning objectives can be achieved. ${ }^{9}$

Mills, argues that "the model is an accurate form of representation as the actual process that allows a person or group of people to try to act on that model". The model is an interpretation of the results of the observation and measurement obtained from several systems. Learning models can be interpreted, the patterns used to arrange curriculum, organize material and give instructions to teachers in class.

The learning model is a pattern that is used as a guide in planning learning in class. According to Arent, the learning model refers to the approach to be used, including in learning objectives, stages in learning activities and classroom management, learning models can be defined as a conceptual framework that illustrates the systematic procedure in organizing learning experiences to achieve learning goals. ${ }^{10}$ Joyce and Weil in Rusman argued that the learning model is a plan or pattern that can be used to shape the curriculum (long-term learning plan), design learning materials and guide learning in class or other. ${ }^{11}$ So, learning models can be used as a pattern of choice,

\footnotetext{
${ }^{9}$ Trianto, Model Pembelajaran Terpadu, (Jakarta; Bumi Aksara, 2010), 51

${ }^{10}$ Agus Suprijono, Cooperative Learning Teori \& Aplikasinya, (Yokyakarta; Pustaka Pelajar, 2010), 45-55

${ }^{11}$ Rusman, Model-model Pembelajaran, (Jakarta; PT. Raja Grafindo Persada, 2011), 133
} 
meaning that teachers can choose appropriate and efficient learning models to achieve their educational goals.

Regarding the learning model, Bruce Joyce and Marsha Weil in Asnawir and Basyirudin Usman, present 4 groups of learning models: "(1) social interaction models, (2) information processing models, (3) personal-humanistic models, and (4) behavior modification models". ${ }^{12}$. Based on this description, in the use of the term learning model identified with learning strategies, which serves to help educators to provide information, ideas, skills, ways of thinking, and expressing ideas to students, and also the learning model functions as a guide for learning designers and students educators in planning teaching and learning activities.

The ideal learning model is "a model that expresses effective learning experiences, namely learning experiences that allow students to experience or act directly and actively in a learning environment". ${ }^{13}$ So the success of the implementation of multicultural Islamic education is very much determined by the program / design arranged by the school and the creativity of Islamic Education teachers in formulating and determining the learning methods. The steps

\footnotetext{
${ }^{12}$ Asnawir dan Basyiruddin Usman, Media Pembelajaran, (Jakarta; Ciputat Pers, 2002), 16

${ }^{13}$ Ismail Sukardi, Model-Model Pembelajaran Modern, (Palembang; Tunas Gemilang Press, 2013), 30
}

taken in compiling the learning program required six important components that must be considered, namely:

(1) identify Competency Standards and Basic Competencies (2) identify study materials / learning materials, (3) develop indicators, (4) develop multicultural learning activities, (5) determine materials / tools / resources used, (6) developing assessment tools that are appropriate to the aspects of life skills. ${ }^{14}$

So from some of the quotes above, the researcher can conclude that the learning model is a set of systematic procedures as a designer for educators to achieve learning goals

\subsection{Multikutural Islamic Education Based on}

\section{Multicultural Values}

Education is life, that is, all learning experiences that take place in all environments. In fact, it is one of the mandatory things used in life, because education is an absolute necessity that must be fulfilled throughout life. ${ }^{15}$

Understanding simply, Education means as an effort to grow and develop innate potentials, both physical and spiritual,

\footnotetext{
${ }^{14}$ AGPAII,Tifa,Rahima dan Ditpai, Panduan Integrasi Nilai Multikultural-Pendidikan Agama Islam, (PT. Kirana Citra Buana; 2011), 97

${ }^{15}$ Redja Mudyahardjo, Pengantar Pendidikan; Sebuah Study Awal Tentang Dasar-dasar Pendidikan pada Umumnya dan Pendidikan di Indonesia, (Jakarta: PT. Raja Grafindo, 2001), 3
} 
in accordance with the values that exist in society. ${ }^{16}$

Education is also often interpreted as an effort to foster personalities in accordance with values in society and culture. In its development, the term Education or pedegogic which means guidance or help is given deliberately by an adult so that he becomes an adult. Furthermore Education is defined as a business carried out by a person or group in order to become an adult or reach a higher level of life in a mental sense.

Based on some of the above definitions, what is meant by Education is a conscious effort or adult activity that consciously directs and guides the growth and development of students towards the formation of a mature and responsible personality.

Islamic Education is one of the means to understand Islam in Kaffah, meaning that Islamic Education should not only focus on increasing the ability of rituals and monotheistic beliefs alone, but also enhance the social morality of humanity and be able to foster critical and creative power. Therefore, the reality of diversity that exists in society is a challenge for Islamic Education to develop Islamic Education learning based on multicultural values. Here Islamic Education is required to reflect,

\footnotetext{
${ }^{16}$ Fuad Ihsan, Dasar-dasar Pendidikan (Rineka Ciopta, 2010), 1-2
} (Rineka Ciopta, 2010), 1-2 including if necessary, revise all or some components of the curriculum that previously tended to be exclusive to an inclusive curriculum so that the function of religious education could be achieved.

Specific characteristics of Islamic Education subjects, one of which is not only to deliver students to master various Islamic teachings, but the most important is how students can practice the teachings of religion every day.

Multicultural education in the concept of Islamic teachings if carefully considered is not uncommon, because of the substance of multicultural education can accept and respect for other people of different races, ethnic groups and customs. In the Qur'an there are a lot of things to talk about, including:

First, humans have the same position with Allah swt, although different tribes, races, cultures, the difference is the quality of his devotion as the word of Allah swt Surah Al-Hujurat verse 13, as stated in Chapter I page 4. It is very firm that Islam basically considers the same as every human being, that is, created and born has the goal to know each other to know and understand the character of each group after these humans become a different group.

Islam always teaches to respect and acknowledge the existence of other people 
with different backgrounds, as the word of Allah swt:

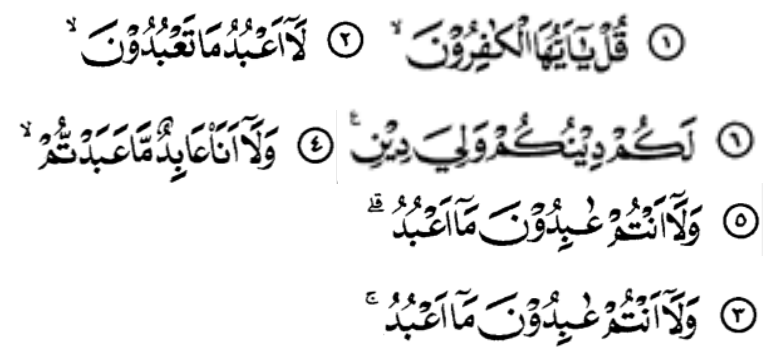

Translation:

Say: O disbelievers. I will not worship what you worship. And you are not the worshipers of God that I worship. And I have never been a worshiper of what you worship. And you have never (also) been a worshiper of the God I worship. For you your religion, and for me, my religion (Q.S Al-Kafirun: 16). ${ }^{17}$

The above verse explains that, Allah teaches Muslims to build an attitude of tolerance in association with fellow humans who are not as faithful as Muslims.

Muslims are instructed to always do good and uphold justice even to nonMuslims, as Allah says:

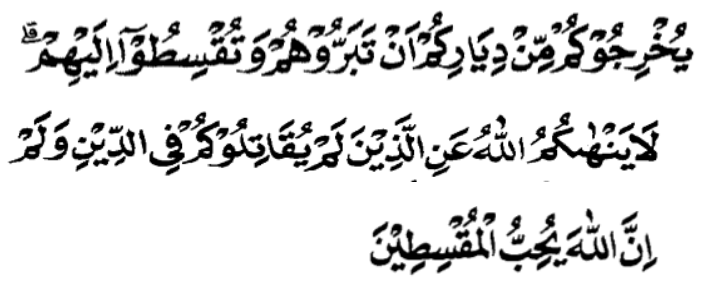

Translation

Allah does not forbid you to do good and be fair to those who do not fight you because of religion and do not (also) expel you from your country.

${ }^{17}$ Departemen Agama RI, al-Qur'an dan terjemahnya, (Surabaya: al-Hidayah, 1998), 112
Indeed, Allah loves those who act justly, (Q.S. al-Mumtahanah: 8). ${ }^{18}$

Based on this verse, there is no reason for Muslims to be radical, apply wrong, be subjective, or act arbitrarily towards other religious communities as long as they are willing to live in harmony and peace with Muslims.

Islam pays great attention to social affairs, if you think deeply, that in essence the mahdhah worship that is prescribed by Allah SWT contains social messages. Like the fasting order, people in carrying out fasting are trained to become human beings who are able to control their desires, such as maintaining the truest feeling of self among others, keeping words that are facile to others, not arbitrary with others, so also those who perform prayers are expected to be private which can prevent cruel and unjust acts, be humble, and respect others. Based on these explanations, it can be said that multicultural education already existed in Islam before prior multicultural education concepts today.

Islamic education based on multicultural values seeks to provide equal opportunities to every member of society to obtain their rights as an independent human being who can express his opinions, have the right to develop his creativity to the full, the

\footnotetext{
${ }^{18}$ Ibid, 924
} 
right to education and the right to justice. The Islamic view reveals that humans are personal and social creatures, personally humans are responsible to God in matters related to social (worship) vertically. As social beings, humans are required to socialize by integrating with other humans to meet all needs. Differences that are not on the human side due to social, economic, racial, and hereditary status should not be over-emphasized so that they ultimately represent divisions in society.

\section{Methodology}

This study uses a qualitative approach with the object of research is Senior High School in Palu City. In this study, the writer took one of the Senior High School to be a case in this study. The school is Senior High School 4 Palu.

Students and educators at Senior High School 4 Palu have different backgrounds. Like the economic background, social, and in terms of diversity. Because of that Islamic education in Senior High School 4 Palu is required to instill the values of multicultural Education in students through developing learning models, so that it attracts the attention of researchers to conduct research at Senior High School 4 Palu.

Data were collected using observation techniques, in-depth interviews and studies from shared written documents. While the data analysis is done using reduction and verification techniques with various data sources. The data that has been reduced is then analyzed by claiming to the theoretical concepts used in this study.

\section{Result and Discussion}

\subsection{Design of Multicultural Islamic Based Development}

Based on the results of the study, Senior High School4 Palu obtained data on the development of a multicultural valuebased Islamic education learning model in the school, as the results of an interview with the vice principal of curriculum, stated:

When talking about Islamic Religious Education based on multicultural values, it certainly starts with a curriculum, therefore, to anticipate this, the existing Islamic Education curriculum, developed by Islamic Education teachers which is here, becomes a multicultural value-based curriculum model, but this conducted on Islamic Education subjects. ${ }^{19}$

Based on this description, it can be understood that the learning of Islamic Education based on multicultural values in Senior High School4 Palu is designed from the curriculum, syllabus, and Lesson Plan. This was added by the following informant:

${ }^{19}$ Sulaiman, Wakil Kepala Sekolah Bidang Kurikulum SMA Negeri 04 Palu, wawancara, Ruang Wakasek, tanggal 9 Juli 2018 
It is true that the curriculum used is the 2013 School-Based curriculum, with a note that in the learning process of integrating multicultural values, the Islamic Education teacher here, the 2013 School-Based curriculum, was developed into a multicultural-based Islamic Education curriculum model that became the basis in describing the syllabus and the lesson plans that they have made so it does not to complicate the teacher in implementing them, and the integration of multicultural values into the curriculum has been implemented. ${ }^{20}$

Based on these two opinions, it can be understood that, the application of the development of multicultural value-based learning models in the learning of Islamic Education in Senior High School4 Palu, was formulated by educators and elaborated on the syllabus and RPP then applied in the learning process. Other information explained as follows:

Islamic Religious Education based on multicultural values in this school, starting from making the design of the development of learning models and syllabus, in this case, the teacher analyzes the learning material of Islamic Education delivered and selects and incorporates multicultural values that are considered appropriate with the material. ${ }^{21}$

${ }^{20}$ Syamzaini, Kepala SMA Negeri 4 Palu, wawancara, Ruang Kepala Sekolah, tanggal 9 Juli 2018

${ }^{21}$ Abd Rasyid, Pendidik Mata Pelajaran Pendidikan Agama Islam dan Budi Pekerti SMA Negeri 4 Palu, wawancara, di Ruang Guru, tanggal 4 Juni 2018
Based on the description above, it can be understood that the implementation of the development of Islamic education learning based on multicultural values in Senior High School4 Palu begins with the creation and development of learning in the syllabus of these subjects. The development process is by analyzing Islamic Education subject matter, then incorporating multicultural values deemed relevant to the material. Then the level of translation is in the learning tool. as explained by the following informant:

The next step is to formulate the Lesson Plan, multicultural values that have been set out in the curriculum, especially in core competency and basic competency, which are then lowered into the syllabus and lesson plan, in making the lesson plan I need to pay attention to the suitability between the subject matter, multicultural values to be developed and the methods used in the delivery of the subject matter to suit and achieve the objectives to be achieved objectives to be achieved. ${ }^{22}$

Based on the explanation above, it can be understood that the development of a multicultural value-based Islamic learning model is formulated in the syllabus, the next step is to translate the multicultural values into the lesson plan by using a multicultural value-based learning model in accordance

${ }^{22}$ Shodikin, Pendidik Mata Pelajaran Pendidikan Agama Islam dan Budi Pekerti SMA Negeri 4 Palu, Wawancara, Ruang Guru, 4 Juni 2018. 
with the learning objectives relevant to the development of Islamic educational learning.

The steps for developing a learning model for Islamic Education based on multicultural values as described by the following informants:

Next is carrying out Islamic Education learning in accordance with a predetermined schedule, in this case, I apply the Islamic Education learning process by incorporating Islamic Education learning based on multicultural values by using group methods that build cooperation between students and try empowers students to develop respect, compassion, solidarity and responsibility. ${ }^{23}$

Based on this description it can be understood that, the development of Islamic Education learning models based on multicultural values in the implementation of Islamic Education learning is very important, because at this stage the process of integrating multicultural values directly in learning, so that teachers develop them requires skills to internalize various sources study right. The results of the analysis of the document that the authors do show that:

In the LessonPlan made by the teacher in Basic Competence 3.3 that is analyzing the meaning of faith in the books of Allah integrated multicultural values are (1) compassion, (2) solidarity, and (3)

${ }^{23}$ Abd Rasyid, Pendidik Mata Pelajaran Pendidikan Agama islam dan Budi Pekerti SMA Negeri 4 Palu, Wawancara, Ruang Guru, 4 Juni 2018 responsibility, in the learning process educators often use lecture methods that make students passive and not in accordance with Islamic education based on muticultural values so that the method is developed using Cooperative learning methods, namely learning that makes students active and based on multicultural values where students are heterogeneous groups according to achievement, gender, ethnicity, race, for the purpose of learning are achieved, educators develop it using the learning model of Wolk Gallery and Poster Commet.

Based on the analysis of the documentation above it can be understood that, Islamic Education is based on multicultural values of Senior High School4 Palu, with the learning model of Gallery Wolk and Poster Comment, that the value of love, when learning students discuss and give each other input to friends or other groups with harmony between them, it is seen when students give criticism, using polite and mutual respect when group members present the results of concepts given by the teacher. The value of solidarity during the learning process and the formation of groups of students falls and behaves in solidarity without differentiating groups / groups of race, ethnicity, religion, attitude and behavior to foster a sense of solidarity towards all people seen when the teacher asks each group to present the results 
of group discussion in front of other groups, The value of responsibility, when the learning process students carry out joint responsibility, is seen when the group leader distributes tasks to each member in the group, full of responsibility where the trainees are done working according to the time agreed upon together.

The multicultural values integrated in the Competency Standards aspects of the lesson are compassionate education, solidarity, and responsibility. These values are not only applied in the classroom, but are implemented in daily activities at school. Therefore the process of internalizing multicultural values requires the support of all parties, as explained by the following informants:

After students know and understand multicultural values learned in the classroom, the next step is to get students to apply these multicultural values to their daily activities at school, for example, to familiarize the application of these values starting from small things to basic things like accustoming greetings, helping friends when they get into trouble, to accustom mutual respect and respect between differences in religion, ethnicity, race, among fellow students. ${ }^{24}$.

Based on the description, it can be understood that, Islamic Education

\footnotetext{
${ }^{24}$ ShodikinPendidik Mata Pelajaran Pendidikan Agama Islam dan Budi Pekerti SMA Negeri 4 Palu, Wawancara, Ruang Wakasek, 4 Juni 2018
}

integrated with multicultural values is not enough to be carried out only in class, but must be followed up in real activities, This is as conveyed by informants that:

we are taught to always maintain togetherness, unity and cooperation between us even though we have different backgrounds, religions, ethnicities, races, and genders, and it is customary among us to greet each other when we meet, both to teachers, fellow students, and to all residents in the school. ${ }^{25}$.

Based on this description, Islamic Education based on multicultural values, can help students to recognize the accuracy of diverse cultural views, help students realize that they cannot live without the help of others, and the need to respect differences between students. Other Islamic education based on multicultural values can be seen through the Lesson Plan, as the researchers can describe as follows:

In the Lesson Plan of the Basic Competence 3.3, multicultural values integrated with Islamic Education learning are carried out in the core activities of the learning process, namely love, so that the students like to help, protect, love among others, solidarity by accustoming students to behave in solidarity without differentiating groups / groups of races, ethnicities, religions, and behaving fostering a sense of

${ }^{25}$ Aini Husnul Amalia, Peserta Didik SMA Negeri 6 Palu, Wawancara, Ruang Kelas, tanggal 01Agustus 2018 
solidarity with all people, and shared responsibility and avoiding mutual suspicion.

\subsection{Approach to the Development of} Multicultural Models of Islamic Education

Senior High School4 Palu has a variety of backgrounds, so in the process of education, the school strives to appreciate these differences in order to appear as an educational institution that has diversity but can coexist in a spirit of togetherness and family. So as to realize this, the Senior High School4 Palu did various things, among others, as the results of the interview with the principal, as follows:

Senior High School 4 Palu has different student backgrounds, this is the main key for me as the principal in making policies related to the education process, the form of policy relating to this is that all teachers must carry out the learning process fairly without discriminating and differentiate students. ${ }^{26}$.

Based on this explanation, the head of Senior High School4 Palu expressly stated that in the education process carried out at the school, it must be based on justice and equality without discriminating between one another. This shows that the education

\footnotetext{
${ }^{26}$ Syam Zaini, Kepala SMA Negeri 4 Palu, wawancara, Ruang Kepala Sekolah, tanggal 06 Juni 2018
}

process carried out at the school shows a multicultural indication in it. Other informants further explained that:

In order to be able to carry out a fair and equitable educational process as affirmed through the principal's policy, we must implement it, among others, by encouraging each student to perform worship in accordance with their respective beliefs in the implementation of the midday prayer for students who are Muslim. ${ }^{27}$.

Based on the description, it can be understood that Senior High School4 Palu try to provide education to students in a fair and equitable manner, especially in worshiping God. And serious efforts from schools provide the best education services for their students. The process of implementing education in accordance with the direction and policy of the school principal, according to one informant:

In the learning process, all students are seen equaly, regardless of religious differences, and ethnic backgrounds of their parents, work background and income of parents, background differences in language, character and so on, all are seen as equals as a student who have the same right to obtain proper education. ${ }^{28}$.

Based on this explanation, it can be understood that the education process carried out at Senior High School4 Palu refers to the

\footnotetext{
${ }^{27}$ Moh. Erwin, Wakil Kepala sekolah Bidang Kesiswaan SMA Negeri 4 Palu, wawancara, Ruang Wakasek, tanggal 04 Juni 2018

${ }^{28}$ Sulaiman, Wakil Kepala Sekolah Bidang Kurikulum SMA Negeri 4 Palu, wawancara, Ruang Wakasek, tanggal 04 Juni 2018
} 
perception that all students regardless of their background are people who need the same Education services, so they must be treated fairly in terms of fulfilling their rights to obtain the same education, for that other informants explained that:

All teachers in this school must have the same view, that is a multicultural view, I do not get tired of always reminding teachers to behave wisely in educating students, they also must promote togetherness and maintain harmony. ${ }^{29}$.

The explanation can be understood that in carrying out the multicultural education process, the educators in Senior High School 4 Palu, must try to equalize the perception in looking at students, that is, multicultural students are seen as equals. Therefore, equality of perception is very important in organizing education, because it can direct education towards achieving the educational goals aspired, so that all educators must understand the importance of multiculturalism and carry out educational processes that are also multicultural in nature, as for the following description explained by the following informants:

To achieve equality in the educational process, all students are fostered, directed and educated according to their potential and talents, so that all students have the same opportunity to show their talents and achievements, then the teacher lives to foster the

${ }^{29}$ Syamzaini, Kepala SMA Negeri 4 palu, wawancara, Ruang kepsek, tanggal 04 Juni 2018 students' talents to be in accordance with national and religious norms. ${ }^{30}$.

The explanation above is that, Senior High School4 Palu provides an opportunity for all students to show and develop their talents and interests, this illustrates that the school supports all students to learn and work in accordance with their talents and interests. From another aspect explained:

In studying Islamic Education, the subject matter is developed by including material that is social in nature and group work, in order to build an understanding of the importance of togetherness. NonMuslim students are directed to a predetermined space to follow the material in accordance with their respective religious teachings. ${ }^{31}$.

Based on these explanations, it can be understood that, the development of learning models of Islamic religious education based on multicultural values in Senior High School4 Palu, among others, is done by adding social material and group work, so as to build students' social lives, these materials are part of the multicultural education to build and familiarize the attitude of working with others. Furthermore that:

${ }^{30}$ Moh.Erwin, Wakil Kepala Sekolah Bidang Kesiswaan SMA Negeri 4 palu, wawancara, Ruang Wakasek, tanggal, 04 Juni 2018

${ }^{31}$ Aswati, Pendidik Mata Pelajaran Pendidikan Agama Islam Dan Budi Pekerti SMA Negeri 4 Palu, wawancara, Ruang Guru, tanggal 06 Juni 2018 
In the learning process of Islamic Education that I carried out, the approach which is to provide equal opportunity to all students to absorb the subject matter, I do not discriminate against any tribes or backgrounds that are owned by students, all the same, as a teacher of course I feel happy when all students are able to absorb the subject matter well, then I always advise students to continue to associate and respect the beliefs held by students of other religions, must not insult or denigrate their religion. ${ }^{32}$.

Based on the description, it can be understood that the approach used in the learning of Islamic Education in Senior High School4 Palu, namely the approach to justice and equality without discrimination, which is called cultural pluralism, which provides equal opportunities for students to learn and accept subject matter without discrimination. - distinguish each other's identity, both from language, ethnicity, and religion. Then providing education to students to get along with non-Muslims and not insult their religion and beliefs, can build harmony and togetherness. This approach is in line with the goal of multicultural education to provide the same educational services to all students, further explained the results of an interview with one of the educators, explaining that:

\footnotetext{
${ }^{32}$ Sainab, Pendidik Mata Pelajaran Pendidikan Agama Islam dan Budi Pekerti SMANegeri 4 Palu, Wawancara, Ruang Guru, tanggal 06 Juni 2018.
}

With the condition of the school students come from different backgrounds, both religion, ethnicity, culture and language, the emphasis in the learning process that $\mathrm{I}$ do is to build and familiarize students to be tolerant in the form of an attitude of respecting these differences, then I also accustom students to choose the path of dialogue, if there is a misunderstanding in the association of students. ${ }^{33}$.

Based on the description, it is understood that, in developing multicultural values in the learning of Islamic Education in Senior High School4 Palu, educators familiarize students to build tolerance for various differences in the school and accustom students to dialogue the problems that arise in activities social interaction between students.

Thus the approach taken by educators at Senior High School4 Palu is to view students as equals by giving opportunities to all students to build and show and develop their respective characteristics, in accordance with the identity they inherited from parents and families both in terms of ethnicity cultural or religious. This shows the efforts of these educational institutions to provide the best for students and for the community who use the school's services.

\footnotetext{
${ }^{33}$ Sodikin, Pendidik Mata Pelajaran Pendidikan Agama Islam dan Budi Pekerti SMA Negeri 4 Palu, Wawancara, Ruang Guru, tanggal 6 Juni 2018
} 


\section{Conclusions}

Design of the development of learning models of Islamic Education based on multicultural values in Senior High School4 Palu are; a) determining multicultural values, which are integrated in Islamic Education lessons, b) syllabus development, educators analyzing subject matter and incorporating multicultural values that are considered relevant with the subject matter into the syllabus, c) describe the syllabus into the Lesson Plan while still including multicultural values, d) use learning methods and models that can support Islamic education learning based on multicultural values, and e) conduct an assessment of the learning process of student learning activities, which is a follow up to the learning that has been learned

\section{References}

Abdullah Ali, Pendidikan Islam Multikultural di Pesanrtren, Yokyakarta; PustakaBelajar, 2011

Abdullah Aly, Pendidikan Islam multicultural di pesantren, Jakarta, Bumi Aksara, 2013.

Abdul Majid, Belajar dan Pembelajaran, Bandung, PT. RemajaRosdakarya, 2012

Abdul Rahman Shaleh, Pendidikan Agama dan KeagamaanVisi, Misi dan Aksi, Jakarta; PT. GemawinduPanca Perkasa, 2000

Abd. Rahman, dkk, Panduan Integrasi Nilai MultikulturalDalam Pendidikan Agama Islam Pada SMA dan SMK,
Jakarta, PT. Kirana Cakra Buana, 2011

Abdul Gafur, Strategi Kepala Sekolah dalam Menerapkan Nilai-nilai Multikultural di Sekolah Menengah Kejuruan (SMK) Negeri Parigi, Tesis, IAIN Palu, 2014 tidak terbitkan

Abdul Majid dan Dian Andayani, Pendidikan Agama Islam

BerbasisKompetensi, Bandung:

RemajaRosdakarya, 2006

Abdul Munir Mulkhan,

KesalehanMultikultural: Ber-Islam secaraAutentik-Kontekstual di ArusPeradaban Global, Jakarta: PSAP, 2005

AchmadFedyaniSaifuddin,

ReposisiPandanganmengenai

Pancasila: Dari Pluralism

keMultikuturalisme, dalamRestorasi

Pancasila;

MendamaikanPolitikIdentitas dan

Modernitas, Bogor, Brighten Press, 2006

AgusSuprijono, Cooperative Learning Teori\&Aplikasinya, Yokyakarta;

PustakaPelajar, 2010

AGPAII,Tifa,Rahima dan Ditpai, Panduan Integrasi Nilai MultikulturalPendidikan Agama Islam, PT. Kirana Citra Buana; 2011

Amin Abdullah, Studi Agama: NormativitasatauHistorisitas,

Yogyakarta: PustakaPelajar, 1996

Anita Lie, Cooperative Laerning di RuangRuang Kelas, Jakarta; PT. Grasindo, 2002

Arifinur, ImplementasiPembelajaran Pendidikan Agama Islam BerwawasanMultikultural

(StudiKasus di SMA SelamatPagi Indonesia Kota Batu), Tesis UIN Maulana Malik Ibrahim Malang 2013 Asnawir dan Basyiruddin Usman, Media Pembelajaran, Jakarta; Ciputat Pers, 2002 
AzyumardiAzra, Pendidikan Multikultural; MembangunKembali Indonesia Bhineka Tunggal Ika, dalamJurnalTsaqofa, Vol, I. No. 2 tahun 2003

Bukhari Umar, Ilmu Pendidikan Islam, Cet.I Jakarta; Amzah, 2010

Choirul

Mahfud,

Pendidikan

MultikulturalYokyakarta:

PustakaPelajar, 2006

Departemen Agama RI, Alqur'an dan terjemahannya, Surabaya; alHidayah, 1998

Dede Rosyida, Pendidikan MultikulturalMelalui Pendidikan Agama, dalamJurnalDidaktikaIslamika, Vol, VI, NoIJuni 2005

Depertemen Pendidikan Nasional, UndangundangNomor 20 Tahun 2003, TentangSistem Pendidikan Nasional, CetI,Jakarta: SinarGrafika, 2003

Departemen Pendidikan Nasional, KamusBesar Bahasa Indonesia, Edisi III Cet III, Jakarta, BalaiPustaka, 2005

Derektorat Pendidikan Agama Islam pada Sekolah, Panduan Model Kurikulum Pendidikan Agama Islam BerbasisMultikulturalSekolahMenen gahAtas, Jakarta; Derektorat Pendidikan Agama Islam Pada SekolahnDerektoratJenderal

Pendidikan Islam Departemen Agama, 2009

Fuad Ihsan, Dasar-dasar Pendidikan, RinekaCipta, 2010.

Galtung, J., Jacobsen, C.G., dan Brand Jacobsen, K.F, (Ed).,Serching For Peace To Transcend, London: Pluto Press., 2002

Hanna, F,J., Hanna, C.A., dan Chung, R.C., Towarda a New Paradigm for Multicultural Counseling, Journal of Ccounseling\& Development, 2001
H.A.R Tilaar, Multiukultural; Tantangantantangan Global Masa DepandalamTransformasi Nasional, Jakarta-Grasindo, 2004,

Hasbullah, Dasar-dasar Pendidikan, Jakarta, PT. Raja Grafindo, 2005.

Haris, I.M,.\& Morrison, M.I.., Peace Education, N.C: McFarland \& Company, 2003

H..M Arifin, KapitaSelekta Pendidikan (Islam dan Umum), Cet.II Jakarta; Bumi Aksara, 1993

Ibrahim Musa, PembelajaranKooperatif, Surabaya; Unesa Press, 2005

Ihsan, Strategi Guru Pendidikan Agama Islam dalammenanamkannilainilaiMutikultural di SMP Negeri 1 Kota Bima, Tesis UIN Maulana Malik Ibrahim Malang 2014

IifKhoiru Ahmadi dan SofanAmri, PaikemGembrot, Jakarta; PT. PrestasiPustakarya, 2011

Imron, Reformasi Pendidikan Agama Islam (PAI) di Era Multikultural, dalam Pendidikan Agama Islam dalamPerspektifMultikulturalisme, Jakarta, BalaiLitbang Agama, 2009

Isjoni, Cooperative Learning EfektifitasPembelajaranKelompok, Bandung; Alfabeta, 2007

Ismail Sukardi, Model-Model Pembelajaran Modern, Palembang; Tunas Gemilang Press, 2013

KokomKomulasari, PembelajaranKontekstualKonsep dan Apliasi, Bandung; PT. RefikaAditama, 2010

Lestari, T.M., dan Tanjung Y, KearifanKunountuk Dunia Modern, MajalahFeminaEdisiTahun 2001

Lexy J. Moleong, Metodologi Penelitian Kualitatif, Cet. XVII Bandung; PT. RemajaRosdakarya, 2002

Made Wena, Strategi Pembelajaran Inovatif Kontenporer, Jakarta; BumiAksara, 2009 
Muhaimin, dkk, Paradigma Pendidikan Islam; Upaya Mengefektifkan Pendidikan Agama Islam di Sekolah Bandung; PT RemajaRosdakarya, 2001

Muhaimin, WacanaPengembangan Pendidikan Agama Islam, PustakaBelajarBelajar, Yogyakarta : 2003

Muhaimin, PengembanganKurikulum Pendidikan Agama Islam: di Sekolah, Madrasah, dan Perguruan Tinggi, Jakarta: Raja GrafindoPersada, 2005

Muhammad Kosim, SistemPembelajaran PAI BerwawasanMultikultural, dalamBalaiPenelitian dan Pengembangan agama Islam, Pendidikan Agama Islam dalamperspektifMultikulturalisme,

Jakarta, Balitbang Agama Jakarta dan PT. SaadahCiptaMandiri, 2009

MuchtarBuchori, Peranan Pendidikan dalampembentukanBudayaPolitik di Indonesia, dalamSindhunata (e), MenggagasParadigmaBaru

Pendidikan Demokratisasi, Otonomi, Civil Saciety, Globalisasi, Yogyakarta; Kanisius, 2000

M.Quraisy Shihab, Tafsir al-Mishbah, Pesan, Kesan dan Keserasian alQur'an, (Jakarta: LenteraHati, 2002, Vol, 15),

NgainunNaim dan Ahmad Syauqi, Pendidikan Multikultural; Konsep dan Aplikasi, Yogyakarta; Ar-Ruzz Media, 2008

Ramayulis, Metodologi Pendidikan Agama Islam Jakarta, Kalam Mulia

RedjaMudyahardjo, Pengantar Pendidikan; Sebuah Study Awal Tentang Dasardasar Pendidikan pada Umumnya dan Pendidikan di Indonesia, Jakarta: PT. Raja Grafindo, 2001.

Rusman, Model-model Pembelajaran, Cet 5, PT. BajagrafindoPersada, Jakarta 2012

Saiful, Penerapan Pembelajaran Multikultural pada Pendidikan Agama Islam di SMA Negeri 6 Sigi,Tesis IAIN Palu 2014
SayyidahSyaehotin, et al., JurnalAntologi Kajian Islam; Tinjauan Tentang Filsafat, Tasawuf, Institut Pendidikan, AlQur"an, Hadits, Hukum, Ekonbomi Islam, (Surabaya: Pascasarjana IAIN SunanAmpel Press, 2006), Cet. Ke-I, 250

Scott Lash dan Mike Featherstone (ed), Recognition and Difference; Politics, Identity, Multiculture London; Sage Publication, 2002

Sapendi, Internalisasi Nilai-nilai Multikultural dalam Pembelajaran Pendidikan Agama Islam di Sekolah (Pendidikan Tanpa Kesadaran), RaheemaJurnalStudi Gender dan Anak IAIN Pontianak Volume 5 Tahun 2013

Stenberg, Wisdom and Its Relations to Intellingence and Creativity, dalam R.J, Stenberg (ed), Wisdom: Its Nature, Origins, and Development, New York: Cambridge University Press, 1990

Tonny D. Widiastono (Ed), Pendidikan Manusia Indonesia, Jakarta; PenerbitBukuKompas, 2004

Trianto, Model PembelajaranTerpadu, Jakarta; BumiAksara, 2010

Undang-undang Sisdiknas (Sistim Pendidikan Nasional) 2003, Jakarta; Cet. I, SinarGrafika, 2003

WardatulBaldah, CecepSumarna dan Bambang Yuniarto, PengaruhPenanaman NilainilaiMultikulturalterhadapPembentu kanSikapPluralisSiswa di MTsNBabakanCiwaringinKabupaten Cirebon, JurnalEdueksos Volume V; No. I Juni 2016,

Zakiyudin Baidhawi, Pendidikan Agama Berwawasan Multikultural, Jakarta, Erlangga, 2005

Zakia Daradjat, Ilmu Pendidikan Islam,Jakarta; Bumi Aksara, 1992

Zubaedi et ai.,Hermeneia; Jurnal Kajian Islam Interdisipliner, Yogyakarta: Program Pascasarjana IAIN Sunan Kali Jaga, Vol 3, No.1, Januari-Juni, 